\title{
Regional differences in supply of organic matter from kelp forests drive trophodynamics of temperate reef fish
}

\author{
J. A. Udy ${ }^{1}$, S. R. Wing ${ }^{1, *}$, S. A. O'Connell-Milne ${ }^{1}$, L. M. Durante ${ }^{1}$, R. M. McMullin ${ }^{1}$, \\ S. Kolodzey ${ }^{1}$, R. D. Frew ${ }^{2}$ \\ ${ }^{1}$ Department of Marine Science, and ${ }^{2}$ Department of Chemistry, University of Otago, PO Box 56, Dunedin 9054, New Zealand
}

\begin{abstract}
Regional differences in trophic structure and availability of alternate sources of basal organic matter to food webs can affect the volume of organic matter converted into fish biomass. The present study combined stable isotope analyses $\left(\delta^{13} \mathrm{C}\right.$ and $\left.\delta^{15} \mathrm{~N}\right)$ with estimates of biomass density of 22 common reef fishes to compare supply of organic matter derived from macroalgae versus phytoplankton to reef fish communities among 30 sites distributed across Fiordland and the Marlborough Sounds, 2 contrasting regions in terms of land-based stressors on the South Island, New Zealand. Fish communities in the Marlborough Sounds were supported by food webs that incorporated less organic matter derived from macroalgae compared to those in Fiordland. Contribution of organic matter derived from macroalgae to fish biomass decreased with trophic level in the Marlborough Sounds, while fishes in Fiordland were supported by a more equal mixture of organic matter derived from phytoplankton and macroalgae among trophic levels. Total fish biomass density was 1.72 times higher in Fiordland, yet the fish community converted 2.91 times more organic matter to fish biomass, as a result of a higher proportion of biomass at high trophic levels. The observed patterns were consistent with limitation in supply of organic matter derived from macroalgae in the Marlborough Sounds, where extensive losses of kelp forest habitat linked to land-based stressors have been reported. The results highlight the importance of considering regional variability in basal organic matter source pools, particularly those produced from sensitive kelp forest habitats, when applying ecosystem-based approaches to managing coastal resources.
\end{abstract}

KEY WORDS: Kelp forest · Reef fish $\cdot$ Trophic level $\cdot$ Organic matter $\cdot$ Food web $\cdot$ Fisheries

\section{INTRODUCTION}

Fisheries production can be constrained by the amount of primary production available at the base of the food web (Ware \& Thomson 2005, Friedland et al. 2012, Watson et al. 2013). Additionally, differences in the trophic structure of the community strongly affect trophodynamics: how energy is transferred up the food web as well as the energy requirements of the community (Pauly \& Christensen 1995). Anthropogenic impacts such as nutrient runoff, increased sedimentation and climate change are altering the

${ }^{*}$ Corresponding author: steve.wing@otago.ac.nz pattern and dynamics of primary production in the world's oceans, particularly in the coastal zone (Johnson et al. 2011, Koenigstein et al. 2016, Krumhansl et al. 2016). Changes of this nature are especially apparent in kelp forest systems, where environmental changes wrought from coastal eutrophication, marine heat waves and proliferation of sea urchins have dramatically modified the distribution and abundance of kelp forests in many parts of the world (Dayton et al. 1998, Wernberg et al. 2016). As a consequence, elucidating the trophic structure of marine communities, and the sources of basal organic matter

(C) The authors 2019. Open Access under Creative Commons by Attribution Licence. Use, distribution and reproduction are unrestricted. Authors and original publication must be credited. 
required to support them, is a vital component of effective ecosystem-based models for fisheries management and for predicting how changes to critical habitats such as kelp forests may affect the functioning of marine ecosystems (Persson et al. 2014, Wing \& Jack 2014, Wing et al. 2015).

The 2 primary sources of basal organic matter for temperate reef communities are phytoplankton and macroalgae (Fredriksen 2003, Koenigs et al. 2015, von Biela et al. 2016), with additional inputs from sea grasses and terrestrial sources in some habitats (Jack et al. 2009, McLeod et al. 2010a). In this context, kelp forest habitats can be extremely productive and provide important autochthonous sources of organic matter for coastal food webs (Mann 1973, Duggins et al. 1989, Koenigs et al. 2015). Macroalgae are consumed directly by herbivorous reef fish, and by invertebrate grazers that then provide prey for omnivorous and predatory reef fish (Graham 2004, Norderhaug et al. 2006, Davenport \& Anderson 2007). Phytoplankton production is more seasonally variable, but nevertheless an important source of organic matter for the food webs underlying most coastal reef fish communities (Koenigs et al. 2015, Docmac et al. 2017, Truong et al. 2017). Organic matter derived from phytoplankton is primarily passed through food webs to reef fish through feeding on zooplankton, migrating pelagic forage fishes (Trebilco et al. 2016, Truong et al. 2017), or suspension feeding invertebrates (Miller \& Page 2012). The relative contribution of organic matter derived from macroalgae and phytoplankton to consumers is strongly influenced by food web structure and the magnitude of inputs from each source at the base. Consequentially differences in the feeding ecology among primary consumers can strongly influence routing of alternate organic matter sources within food webs and result in large differences in the contribution of alternate basal organic matter sources to higher trophic level species.

Primary consumers tend to derive a high proportion of their organic matter from a single source, either phytoplankton or macroalgae (Rooney et al. 2006, Hamilton et al. 2014). At higher trophic levels, secondary and tertiary consumers are supported by a more even mixture of the available organic matter sources as the variety of underlying trophic connections increases (McMeans et al. 2013, Koenigs et al. 2015). In diverse communities, coupling of different energy channels at high trophic levels confers stability in food webs (Rooney et al. 2006). Theoretically, if higher trophic level consumers are better able to integrate prey, then the food web should have a 'hump shaped' structure when graphed on axes of percent contribution of alternate organic matter sources versus trophic level (McMeans et al. 2013). Rooney et al. (2006) demonstrated that this relationship is present across a diverse variety of ecosystems. For example, in coastal marine systems, if both primary sources of organic matter, in the present case macroalgae and phytoplankton, are sufficiently available, top level consumers will be supported by an approximately equal mixture of organic matter derived from the 2 sources (Rooney et al. 2006).

As a result of their high trophic level, reef fish act as effective integrators for the flux of organic matter from macroalgae and phytoplankton through coastal food webs (Thomas \& Cahoon 1993, Vander Zanden \& Vadeboncoeur 2002, Hamilton et al. 2011). A majority of temperate reef fish employ generalist feeding strategies, and their diets reflect the relative availability of their prey, and hence the relative availability of the basal organic matter sources for the food webs that support those prey (Cowen 1986, McLeod et al. 2010b, Jack \& Wing 2011). Consequently, if 1 organic matter source is limited, then one would expect the top predators to acquire the majority of their organic matter from the alternate, more abundant, source (McCann \& Rooney 2009).

As organic matter is transferred up the food web, approximately $90 \%$ is lost in terms of biomass with each trophic transfer (Pauly \& Christensen 1995, Ware 2000). As a consequence, the amount of basal organic matter required to support a fish at trophic level 4 is an order of magnitude higher than the organic matter required to support a fish of equal biomass at trophic level 3. Therefore, if supply of one organic matter source is limited, then as organic matter is transferred up the food web to higher trophic levels, the proportion of organic matter acquired from the alternate, more abundant, source will increase (McCann \& Rooney 2009). In this context, for temperate reef fishes, if the supply of organic matter derived from kelp forests is limited, then high trophic level fish may increase their use of subsidies from external pelagic sources to meet their high energy demands (Trebilco et al. 2016). These relationships provide a valuable method for resolving patterns in limitation of basal organic matter supply within natural food webs.

Kelp forests are currently under threat from a variety of anthropogenic activities with evidence for widespread losses of kelp bed habitat along coastlines worldwide (Dayton et al. 1998, Steneck et al. 2002, Connell et al. 2008). Macroalgae are an important organic matter source for many reef fish commu- 
nities (Koenigs et al. 2015, von Biela et al. 2016); therefore, a contraction of kelp forest habitats may affect the structure, stability and productivity of temperate reef food webs (McMeans et al. 2013, Markel \& Shurin 2015). A corollary is that patterns in the incorporation of basal organic matter from macroalgae into coastal food webs provides a metric for how regional differences in the prevalence of kelp forest habitats affect trophodynamics of fishes.

Here we were able to directly test these ideas by comparing the trophic architecture, origins and volume of organic matter supporting coastal fish communities from 2 contrasting regions, Fiordland and the Marlborough Sounds. Both regions are characterized by extensive wave-sheltered rocky reef habitats at the entrances of the sounds, harboring kelp forests with both giant kelp Macrocystis pyrifera and the common kelp Ecklonia radiata, as well as similar reef fish and benthic invertebrate communities (Shears \& Babcock 2007, Wing \& Jack 2014). Nevertheless, there have been declines reported in giant kelp forests in the Marlborough Sounds over the last $50 \mathrm{yr}$ linked to marine heat waves (Hay 1990) and increases in fine sediment inputs (Handley 2016), and following the overharvesting of the sea urchin predators red rock lobster Jasus edwardsii and blue cod Parapercis colias (Davidson et al. 2014). In contrast, Fiordland is a relatively pristine region with few land-based stressors (Tallis et al. 2004), intact native forest catchments contained within a national park (Wing \& Jack 2014) and extensive, multilayered kelp forest habitats (Miller et al. 2006, Wing et al. 2007). Regardless of the causal mechanisms, observed differences in prevalence of kelp forest habitat between the 2 regions provides an important scientific opportunity to answer the question: How do regional differences in extent of kelp forest habitats affect supply of organic matter to food webs supporting reef fish communities?

Stable isotope analysis provides a repeatable method for estimating an animal's trophic position, as the isotopic signature of an animal's tissues reflects that of its diet (Deniro \& Epstein 1978, 1981). Owing to basic differences in acquisition of inorganic carbon, phytoplankton and macroalgae can, in many circumstances, each have characteristic values of $\delta^{13} \mathrm{C}$ (e.g. Jack \& Wing 2011). Therefore, $\delta^{13} \mathrm{C}$ can be used to determine the relative contribution of organic matter derived from the alternate sources to a consumer (Fry 2006). There is also a predictable increase in $\delta^{15} \mathrm{~N}$ with each trophic exchange; therefore, the $\delta^{15} \mathrm{~N}$ of a consumer's tissues can be used to determine its integrated trophic level (McCutchan et al. 2003).
In the present study, we used stable isotope analyses to determine the trophic level of, and contribution of organic matter derived from macroalgae to the 22 most common fish species in the temperate reef communities of Fiordland and the Marlborough Sounds, New Zealand. We then combined information on density, per-capita biomass and trophic position of the reef fish species in each region to investigate: (1) how biomass was distributed across trophic levels in the reef fish communities, and (2) how much of the biomass at each trophic level was supported by macroalgae. A regional comparison of this relationship allowed us to address how limited local abundance of kelp forest habitats may have affected supply of organic matter to food webs supporting reef fish communities.

Information on the trophic level and relative biomass of each of the 22 species was then used to estimate: (3) the total amount of basal organic matter from macroalgae and phytoplankton that was required to support the temperate fish communities on a per unit area basis, and (4) the sensitivity of our results to a range of trophic transfer efficiencies. Here we were able to compare how regional differences in trophic structure related to differences in the energy requirements of the 2 communities. In these analyses, we asked whether the proportion of fish biomass supported by organic matter derived from macroalgae versus phytoplankton was constant across trophic levels or if 1 organic matter source became more predominantly used by higher trophic levels, as a measure of the relative availability of the alternate sources. These data have important implications for understanding the role of kelp forest habitats as a source of basal organic matter for supporting coastal reef fish communities in the context of ecosystembased management. In a management context, these data not only highlight the role of kelp forests as a vital provider of biogenic habitat for reef fish but also reveal these habitats as an important source of organic matter supporting coastal food webs.

\section{MATERIALS AND METHODS}

\subsection{Surveys of reef fish density}

The density of reef fish in each region was estimated using underwater visual census. Divers using SCUBA recorded the abundance of all fish observed along belt transects ( $50 \mathrm{~m}$ long by $5 \mathrm{~m}$ wide by $2.5 \mathrm{~m}$ high) centered at 5 and $15 \mathrm{~m}$ depths at each study site. Four independent replicate transects were 
surveyed at each depth for each of the 30 sites $(\mathrm{n}=$ 240) giving a total area surveyed of $60000 \mathrm{~m}^{2}$. The composition of diver teams identifying and counting fishes was kept constant for the duration of the study. Diving surveys in the Marlborough Sounds were conducted during January 2017 (8 sites) and February 2018 (4 sites), and surveys in Fiordland were conducted during November 2015 (11 sites) and May 2017 (7 sites). Study sites were confined to rocky reef habitat in each region and were stratified in a factorial design among wave-exposed (generally more macroalgae) and wave-sheltered sites (generally fewer macroalgae) and within fished areas and marine reserves, in order to sample a representative range of rocky reef habitats within each region (Fig. 1).

\subsection{Trophic position of reef fish}

For each of the 22 fish species observed on the belt transects, a random sample of individuals was collected from each region, using a combination of hook and line and pole spears (total $\mathrm{n}=775$, minimum sample size of 5 for common species). Sampling was carried out during austral summer (January and February) of 2017 and 2018 under permit from the New Zealand Ministry of Primary Industries and under ethical approval from the University of Otago animal ethics committee (ET 21/11). Collections using pole spears enabled us to sample a random selection of individuals stratified within discrete size ranges for the most common species for each region (e.g. blue cod Parapercis colias) in order to account for any ontogenetic shifts in diet between juvenile and adult phases.

Fish were frozen and transported back to the Portobello Marine Laboratory where dorsal muscle tissue samples were dried at $60^{\circ} \mathrm{C}$ for $48 \mathrm{~h}$, ground to a fine powder using mortar and pestle and $1 \mathrm{mg}$ subsamples were sealed into tin capsules for measurement of $\delta^{13} \mathrm{C}$ and $\delta^{15} \mathrm{~N}$. Lipids were not extracted from muscle tissue before isotopic analysis as the $\mathrm{C}: \mathrm{N}$ ratio was found to be between 3.5 and 4 for all species. These values were below critical values for determining whether lipid extraction was required, and as we were comparing the same species between regions, lipid extraction was not deemed necessary (Post et al. 2007, Skinner et al. 2016).

Suspended particulate organic matter (SPOM) was collected from each site using a $20 \mu \mathrm{m}$ plankton net vertically cast through the water column from $15 \mathrm{~m}$ to the surface $(n=30)$. SPOM samples were passed through a $250 \mu \mathrm{m}$ filter to remove zooplankton and
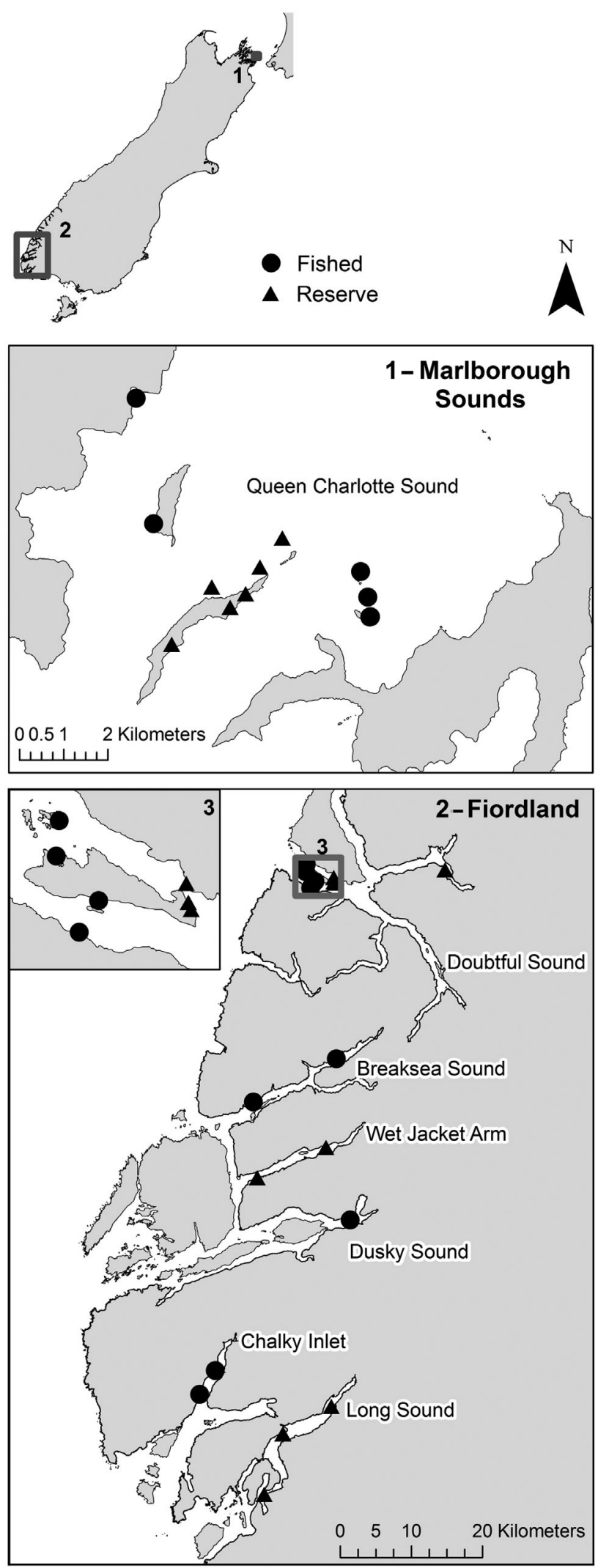

Fig. 1. Location of study sites in the Marlborough Sounds and Fiordland Marine Area, New Zealand. Centers of regional maps are located at: Fiordland $45^{\circ} 38^{\prime} 16.71^{\prime \prime} \mathrm{S}, 166^{\circ}$ 51' 8.72" E, Marlborough Sounds $41^{\circ} 6^{\prime} 6.80^{\prime \prime} \mathrm{S}, 174^{\circ} 18^{\prime} 31.46^{\prime \prime} \mathrm{E}$ 
whole bulk samples were used for isotopic analysis. We examined samples microscopically to confirm that they were primarily made up of phytoplankton. For each common macroalgal species present at a study site, for example Macrocystis pyrifera, Ecklonia radiata, Cystophora spp., Carpophyllum spp., Undaria pinnatifida and Ulva spp., blade tissue was collected by divers from multiple individuals $(n=5)$ stratified by depth. Samples of SPOM and macroalgae were dried at $60^{\circ} \mathrm{C}$ for $48 \mathrm{~h}$ and ground into a fine powder using mortar and pestle. Powder from SPOM and macroalgae samples were weighed to $3 \mathrm{mg}$ and sealed into tin capsules for measurement of $\delta^{13} \mathrm{C}$ and $\delta^{15} \mathrm{~N}$.

Analysis of $\delta^{15} \mathrm{~N}$ and $\delta^{13} \mathrm{C}$ of fish, SPOM and macroalgae was carried out on a 20-20 update stable isotope mass spectrometer (Europa Scientific) interfaced to an elemental analyzer (NA1500; Carlo Erba) in continuous flow mode (precision: $0.2 \%$ for $\delta^{13} \mathrm{C}$, $0.3 \%$ for $\delta^{15} \mathrm{~N}$ ) at Isotrace Research in the Department of Chemistry, University of Otago. Raw results were calibrated to international scales using USG40 and USG41 reference materials. An in-house laboratory standard (EDTA, Elemental Microanalysis) was used to check the method's precision and accuracy. Drift corrected data are reported with respect to the appropriate international reference standard; atmospheric air for $\delta^{15} \mathrm{~N}$ and Vienna Pee Dee Belemnite for $\delta^{13} \mathrm{C}$. The isotope ratio was expressed in standard delta notation (Fry 2006). Variability in sample replicates within trays was estimated by calculating the average variance and standard deviation for $\delta^{15} \mathrm{~N}$ and $\delta^{13} \mathrm{C}$. As the standard deviation was less than $2 \%$ of the mean for all samples replicated within trays, we concluded that instrument drift within a run was low and very unlikely to mask true differences in isotopic signatures among groups.

The relative abundance of each macroalgal species, as determined from density data from each site, was used to calculate aggregate macroalgal values for $\delta^{15} \mathrm{~N}$ and $\delta^{13} \mathrm{C}$ with variance stratified among species (after Wing et al. 2012). Average values of $\delta^{15} \mathrm{~N}$ and $\delta^{13} \mathrm{C}$ for phytoplankton-derived and macroalgaederived organic matter were then calculated for each region, with variance among sites (see Table 1). For all fish, except the 2 herbivorous species, a 2-step iterative procedure was used to determine the trophic level and the origin of basal organic matter based on $\delta^{15} \mathrm{~N}$ and $\delta^{13} \mathrm{C}$ of each individual (Jack \& Wing 2011). A 2-source mass balance model after Phillips \& Gregg (2001) was used to estimate the relative contribution of organic matter derived from macroalgae and phytoplankton to each individual using $\delta^{13} \mathrm{C}$. Initially, an approximation of trophic level was used to estimate the trophic discrimination of $\delta^{13} \mathrm{C}$. The results were then used to estimate the corresponding $\delta^{15} \mathrm{~N}$ of the mixture of organic matter sources at the base of the food web $\left(\delta^{15} \mathrm{~N}_{\text {base }}\right)$. The trophic level was then recalculated for each individual from $\delta^{15} \mathrm{~N}_{\text {base, }}$ defined as: $\left(\delta^{15} \mathrm{~N}_{\text {consumer }}-\delta^{15} \mathrm{~N}_{\text {base }} /\right.$ $\Delta_{\mathrm{n}}$ ), where $\Delta_{\mathrm{n}}$ is the trophic discrimination factor, after Post (2002). The resulting estimate of the trophic level was then iterated back into the mass balance model until a stable solution was obtained. We used trophic discrimination factors of $+0.5 \pm$ $0.17 \%$ o (mean $\pm \mathrm{SE}$ ) for $\Delta^{13} \mathrm{C}$, and $+2.3 \pm 0.28 \%$ for $\Delta \Delta^{15} \mathrm{~N}$, after McCutchan et al. (2003). Trophic discrimination factors can vary between taxa and systems (Newsome et al. 2010). However, as we were comparing the same species between regions, any errors introduced by the use of an average discrimination factor should not have affected the detection of regional differences in trophic position.

For the 2 strictly herbivorous species, greenbone Odax pullus and marblefish Aplodactylus arctidens, we used estimates of the trophic level and mass balance estimates as above, but considered alternative sources of organic matter from within the macroalgal community. O. pullus and A. arctidens were found to be strictly herbivorous, based on examination of diet from stomach content samples. Primary consumers can have a more variable trophic discrimination factor $\Delta^{15} \mathrm{~N}$ than the average value among trophic transfers found in higher trophic level consumers. Therefore, we used an average of the $\Delta^{15} \mathrm{~N}(+4.62 \pm 0.17 \%)$ reported for 3 herbivorous fishes by Mill et al. (2007) for our mixing models of herbivorous fish.

\subsection{Biomass distribution across trophic positions}

Average wet weight $(\mathrm{g})$ was calculated for each fish species collected for isotopic analysis within each region. To determine the per-capita ash-free dry weight $(\mathrm{g})$ for each species, a subset of the fish collected were dried at $60^{\circ} \mathrm{C}$ for $48 \mathrm{~h}$ and then weighed, combusted in a muffle furnace at $500^{\circ} \mathrm{C}$ for $24 \mathrm{~h}$ and reweighed. The ash-free dry weight $(\mathrm{g})$ for each species was used to develop an equation for ash-free dry weight, or biomass, from wet weight (biomass $[\mathrm{g}]=$ $0.2206 \times$ wet weight $\left.[g], \mathrm{r}^{2}=0.96\right)$. This conversion factor was then used to convert the average wet weight of each fish species for each region into an average per-capita biomass per species.

Fishing influences population size structure. Therefore, abundance of common exploited species was 
stratified by size classes. For example, blue cod $P$. colias) was stratified into 3 size classes $(<15,15-33$, $>33 \mathrm{~cm}$ ) while blue moki Latridopsis ciliaris was stratified into 2 size classes $(<40,>40 \mathrm{~cm})$. Average per-capita weight by size class was calculated for these species and a conversion factor was used to estimate the per-capita biomass $(g)$ for each size class, and for the population.

For each transect, species abundance was multiplied by the specific average per-capita biomass. Biomass of each species was then multiplied by the average proportion of biomass that was supported by organic matter derived from macroalgae for that species (based on mass balance calculations from stable isotope data, see Sections 2.1 and 2.2). From these data the average biomass of each species and the average biomass supported by organic matter derived from macroalgae of each species was calculated. Plots of cumulative fish biomass and cumulative fish biomass supported by organic matter derived from macroalgae by trophic level, for both Fiordland and Marlborough, allowed visualization of how the proportion of fish biomass supported by organic matter derived from macroalgae changed with trophic level and of how the distribution of biomass across trophic levels differed between regions.

For each transect, the total biomass and the biomass supported by organic matter derived from macroalgae was summed among species to give a total biomass (g $250 \mathrm{~m}^{-2}$ ) and biomass supported by organic matter derived from macroalgae $\left(\mathrm{g} 250 \mathrm{~m}^{-2}\right.$ ). Dividing the amount of biomass supported by organic matter derived from macroalgae by the total amount of biomass gave the proportion of biomass supported by organic matter derived from macroalgae on each transect. General linear models (JMP 11.0 SAS) with factors REGION (2 levels, fixed) and SITE [REGION] (30 levels, random) were used to test for regional differences in: (1) total fish biomass, (2) fish biomass supported by organic matter derived from macroalgae, (3) fish biomass supported by phytoplankton-derived organic matter and (4) proportion of fish biomass supported by macroalgae-derived organic matter.

The proportion of total cumulative fish biomass supported by organic matter derived from macroalgae at each trophic level was calculated. A general linear model with factors REGION (fixed, 2 levels) and TROPHIC LEVEL [REGION] (continuous) was used to test whether there was a relationship between the proportion of cumulative fish biomass supported by organic matter derived from macroalgae and trophic level and whether the slope of the rela- tionship differed between regions. Herbivores ( $O$. pullus and $A$. arctidens) were excluded from this analysis. Use of cumulative biomass in this case allowed one to visualize the total biomass below each trophic level that was supported by a particular organic matter source. Further, one could then test how the proportion of organic matter derived from any 1 source changed continuously through the food web.

\subsection{Organic matter required to support reef fish community}

For each transect, we calculated the amount of organic matter required to support the biomass of each species observed using the following formula, where TE is the transfer efficiency:

$$
\text { Organic matter biomass }(g)=\frac{\text { Fish biomass }(g)}{T^{\text {TrophicLevel }}}
$$

Trophic level was calculated for each species assuming primary producers were at trophic level 0 . Here we used an average transfer efficiency of 0.1 for the transfer of organic matter between each trophic level (Pauly \& Christensen 1995, Ware 2000). The amount of organic matter biomass required to support each species was multiplied by the proportion of that species' biomass supported by organic matter derived from macroalgae, to give the amount of macroalgae biomass required to support each species. For each transect, the biomass of organic matter and the biomass of organic matter derived from macroalgae was summed among species to give total organic matter biomass $\left(\mathrm{g} 250 \mathrm{~m}^{-2}\right)$ and organic matter biomass derived from macroalgae $\left(\mathrm{g} 250 \mathrm{~m}^{-2}\right)$ that was needed to support the reef fish community. Dividing the amount of organic matter derived from macroalgae by the total amount of organic matter required gave the proportion of organic matter derived from macroalgae on each transect. The amount of organic matter derived from phytoplankton was calculated as the difference between total organic matter and organic matter derived from macroalgae. General linear models (JMP 11.0 SAS) with factors REGION (2 levels, fixed) and SITE [REGION] (30 levels, random) were used to test for regional differences in: (1) total organic matter, (2) organic matter derived from macroalgae, (3) organic matter derived from phytoplankton and (4) proportion organic matter derived from macroalgae.

As trophic efficiencies can vary between taxa and systems (Ware 2000, Barnes et al. 2010), we tested 
Table 1. Isotopic signatures $\left(\delta^{13} \mathrm{C}\right.$ and $\delta^{15} \mathrm{~N}$, mean $\left.\pm \mathrm{SE}\right)$ used in mass balance mixing models for each organic matter source and reef fish species observed on transects in Fiordland and in the Marlborough Sounds, New Zealand. Empty cells indicate that no individuals of the species were found

\begin{tabular}{|c|c|c|c|c|c|}
\hline \multirow[t]{2}{*}{ Species } & \multirow[t]{2}{*}{ Common name } & \multicolumn{2}{|c|}{ Fiordland } & \multicolumn{2}{|c|}{ Marlborough } \\
\hline & & $\delta^{13} \mathrm{C}$ & $\delta^{15} \mathrm{~N}$ & $\delta^{13} \mathrm{C}$ & $\delta^{15} \mathrm{~N}$ \\
\hline & SPOM & $-21.60 \pm 0.19$ & $3.86 \pm 0.95$ & $-21.05 \pm 0.24$ & $6.69 \pm 0.25$ \\
\hline & Macroalgae & $-17.48 \pm 0.24$ & $5.40 \pm 0.35$ & $-14.99 \pm 0.73$ & $6.88 \pm 0.21$ \\
\hline Caesioperca lepidoptera & Butterfly perch & $-17.86 \pm 0.12$ & $13.05 \pm 0.16$ & $-19.52 \pm 0.37$ & $13.29 \pm 0.36$ \\
\hline Mendosoma lineatum & Telescope fish & $-17.85 \pm 0.44$ & $12.43 \pm 0.61$ & & \\
\hline Pseudolabrus miles & Scarlet wrasse & $-17.74 \pm 0.13$ & $14.53 \pm 0.18$ & $-17.62 \pm 0.83$ & $13.13 \pm 0.81$ \\
\hline Notolabrus celidotus & Spotty & $-17.79 \pm 0.08$ & $12.47 \pm 0.11$ & $-17.48 \pm 0.23$ & $14.31 \pm 0.22$ \\
\hline Parapercis colias & Blue cod & $-17.07 \pm 0.10$ & $13.27 \pm 0.13$ & $-17.88 \pm 0.19$ & $14.52 \pm 0.18$ \\
\hline Notolabrus fucicola & Banded wrasse & $-17.98 \pm 0.16$ & $13.72 \pm 0.22$ & $-16.43 \pm 0.34$ & $13.85 \pm 0.33$ \\
\hline Aplodactylus arctidens & Marblefish & $-21.09 \pm 0.39$ & $10.62 \pm 0.55$ & $-19.71 \pm 0.48$ & $12.73 \pm 0.47$ \\
\hline Nemadactylus macropterus & Tarakihi & $-16.44 \pm 0.25$ & $13.75 \pm 0.35$ & $-16.88 \pm 0.59$ & $14.78 \pm 0.57$ \\
\hline Notolabrus cinctus & Girdled wrasse & $-17.72 \pm 0.31$ & $13.48 \pm 0.43$ & & \\
\hline Parika scaber & Leatherjacket & $-17.99 \pm 0.39$ & $12.99 \pm 0.55$ & $-18.57 \pm 0.83$ & $13.00 \pm 0.81$ \\
\hline Helicolenus percoides & Sea perch & $-17.55 \pm 0.17$ & $13.48 \pm 0.43$ & & \\
\hline Latridopsis ciliaris & Blue moki & $-16.46 \pm 0.39$ & $13.63 \pm 0.55$ & $-17.02 \pm 0.28$ & $13.27 \pm 0.27$ \\
\hline Odax pullus & Greenbone & $-16.29 \pm 0.44$ & $9.14 \pm 0.61$ & $-15.97 \pm 0.59$ & $9.96 \pm 0.57$ \\
\hline Latris lineata & Trumpeter & $-17.62 \pm 0.62$ & $12.93 \pm 0.87$ & & \\
\hline Latridopsis forsteri & Copper moki & $-19.00 \pm 0.62$ & $13.31 \pm 0.87$ & & \\
\hline Hypoplectrodes huntii & Red-banded perch & $-17.22 \pm 0.88$ & $14.88 \pm 1.23$ & & \\
\hline Lotella rhacinus & Red cod & $-15.77 \pm 0.44$ & $13.25 \pm 0.61$ & & \\
\hline Callanthias allporti & Splendid perch & $-17.77 \pm 0.88$ & $14.09 \pm 1.23$ & & \\
\hline Paratrachichthys trailli & Common roughy & $-17.83 \pm 0.88$ & $14.05 \pm 1.23$ & & \\
\hline Cheilodactylus spectabilis & Red moki & & & $-17.11 \pm 0.59$ & $14.56 \pm 0.57$ \\
\hline Arripis trutta & Kahawai & & & $-18.82 \pm 0.41$ & $14.67 \pm 0.41$ \\
\hline Aldrichetta forsteri & Yellow-eyed mullet & & & $-17.83 \pm 0.31$ & $12.96 \pm 0.31$ \\
\hline
\end{tabular}

the sensitivity of our estimates of organic matter required to support the fish community to a range of values of transfer efficiency. We calculated organic matter required as above, but using transfer efficiency values ranging from 0.05 to 0.2 for the calculation of the total organic matter biomass required to support each species (Barnes et al. 2010). General linear models (JMP 11.0 SAS) with factors REGION (2 levels, fixed) and SITE [REGION] (30 levels, random) were used to test for regional differences in the total amount of organic matter required to support the fish community, as calculated using the range of reported transfer efficiencies.

\section{RESULTS}

\subsection{Trophic position of reef fish}

$\delta^{13} \mathrm{C}$ and $\delta^{15} \mathrm{~N}$ of phytoplankton and macroalgae, as well as those of fishes were well differentiated among regions (Table 1). The resulting shape of the cumulative distribution of reef fish biomass among trophic levels varied between regions (Fig. 2). Here the distribution of reef fish biomass among trophic levels extended to higher trophic levels in Fiordland than the Marlborough Sounds (Fig. 2). In Fiordland, the highest average trophic level was $4.02 \pm 0.51$ (Hypoplectrodes huntii), while in the Marlborough Sounds Nemadactylus macropterus occupied the highest average trophic level at $3.336 \pm 0.2316$.

\subsection{Biomass distribution across trophic positions}

Total fish biomass (g $250 \mathrm{~m}^{-2}$ ) was significantly higher in Fiordland than in the Marlborough Sounds $\left(F_{1,189}=5.1618, \mathrm{p}=0.0308, \mathrm{r}^{2}=0.3711\right)$ (Figs. $\left.2 \& 3\right)$. Along with the greater fish biomass, there was a greater amount of fish biomass supported by organic matter derived from macroalgae in Fiordland $\left(F_{1,186}=\right.$ 12.96, $\mathrm{p}=0.0012, \mathrm{r}^{2}=0.422$ ) (Fig. 3). Nevertheless, there was no regional difference in the amount of fish biomass supported by organic matter derived from phytoplankton $\left(F_{1,186}=1.3624, \mathrm{p}=0.2527, \mathrm{r}^{2}=0.3313\right)$. Consequently, organic matter derived from macroalgae supported a greater proportion of total reef fish biomass in Fiordland $(49.32 \pm 1.08 \%)$ than in the Marlborough Sounds $(33.57 \pm 0.62 \%)\left(F_{1,186}=182.59\right.$, $\mathrm{p}<0.0001)$. 
There was a significant regional difference in the slope of the relationship between trophic level and the proportion of cumulative fish biomass supported by organic matter derived from macroalgae (Main Test: $F_{3,26}=25.26, \mathrm{p}<0.0001$; TROPHIC LEVEL [REGION]: $F=37.88, \mathrm{p}<0.0001$; REGION: $F=30.16$,

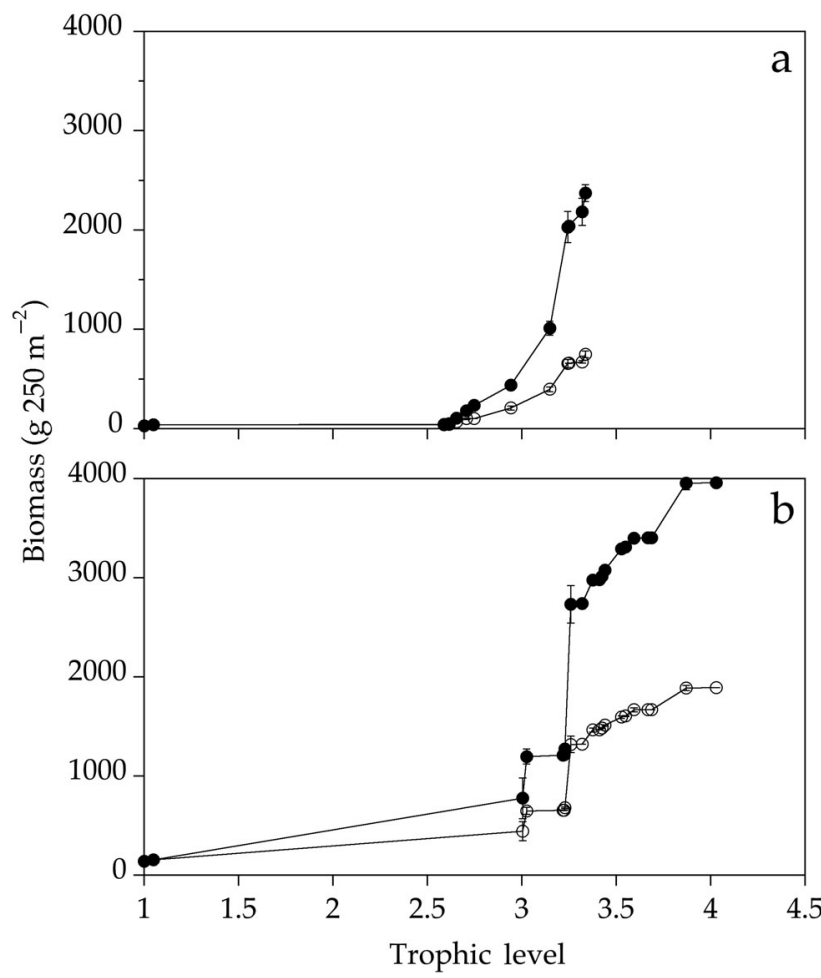

Fig. 2. Cumulative average fish biomass $\left(\mathrm{g} 250 \mathrm{~m}^{-2}\right)$ (0) and cumulative average fish biomass supported by organic matter derived from macroalgae (g $250 \mathrm{~m}^{-2}$ ) (O) versus trophic level for temperate reef fish observed on transects in (a) the

Marlborough Sounds and (b) Fiordland. Mean \pm SE

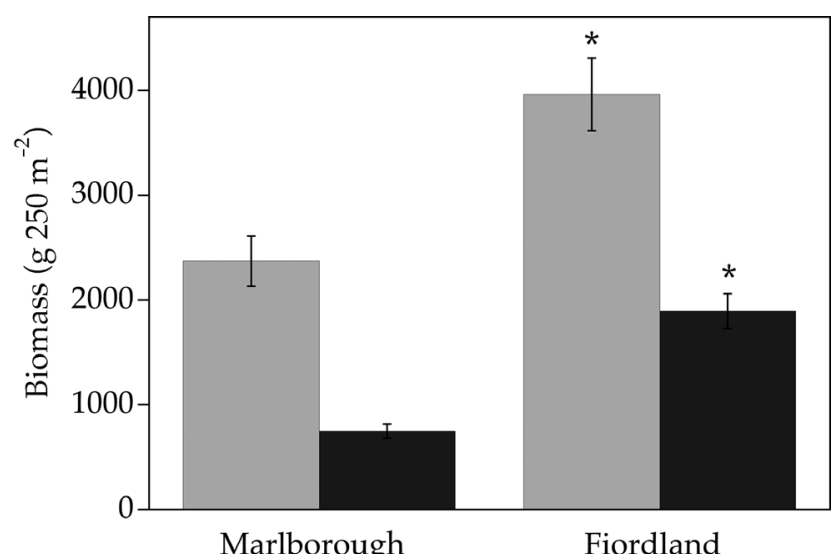

Fig. 3. Average fish biomass ( $\mathrm{g} 250 \mathrm{~m}^{-2}$ ) (口) and amount of fish biomass supported by organic matter derived from macroalgae (ם). Error bars indicate $\pm 1 \mathrm{SE}^{*}{ }^{*}$ significant regional differences at $\mathrm{p}<0.05$ $\mathrm{p}<0.0001$ ). In the Marlborough Sounds, the proportion of cumulative fish biomass supported by organic matter derived from macroalgae declined with increasing trophic level $(t=-8.61, \mathrm{p}<0.0001)$; however, in Fiordland there was no relationship between trophic level and proportion of cumulative fish biomass supported by organic matter derived from macroalgae ( $t=-1.30, \mathrm{p}=0.2054)$ (Fig. 4).

\subsection{Organic matter required to support reef fish communities}

Using an average transfer efficiency of $10 \%$, the Fiordland reef fish community required a greater biomass of basal organic matter to support them than did the Marlborough Sound reef fish community $\left(F_{1,189}=11.257, \mathrm{p}=0.0022, \mathrm{r}^{2}=0.5816\right)$ (Fig. 5). The Fiordland fish community incorporated more organic matter derived from macroalgae $\left(F_{1,189}=17.5579, \mathrm{p}=\right.$ $\left.0.0002, \mathrm{r}^{2}=0.6126\right)$ and from phytoplankton $\left(F_{1,186}=\right.$ 7.3939, $\mathrm{p}=0.0110, \mathrm{r}^{2}=0.5423$ ) into fish biomass, on a per unit area basis $\left(\mathrm{g} 250 \mathrm{~m}^{-2}\right)$ (Figs. 5 \& 6a). The fish communities in both regions derived over $50 \%$ of their organic matter from phytoplankton, although the proportion of organic matter derived from macroalgae was greater in the Fiordland reef fish community $(46.41 \% \pm 0.75 \%)$ than in the Marlborough Sounds reef fish community $(31.37 \% \pm 0.56 \%)\left(F_{1,189}=\right.$ 75.3495, $\mathrm{p}<0.0001, \mathrm{r}^{2}=0.8135$ ) (Fig. 6b). While the total fish biomass was 1.72 times higher in Fiordland than in the Marlborough Sounds, the Fiordland fish community consumed and integrated 2.91 times more organic matter. Further, the Fiordland fish community made use of 4.44 times more organic matter

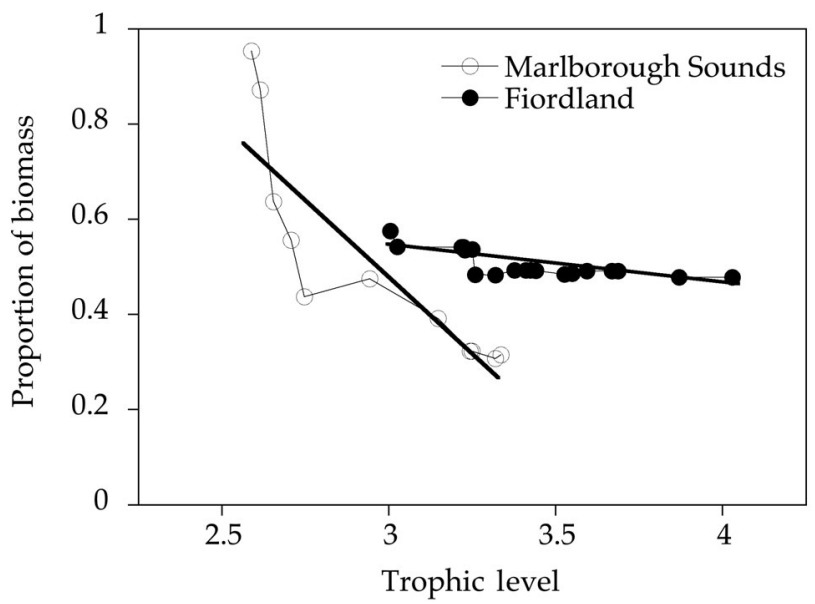

Fig. 4. Proportion of cumulative fish biomass supported by organic matter derived from macroalgae versus trophic level for Fiordland and the Marlborough Sounds 


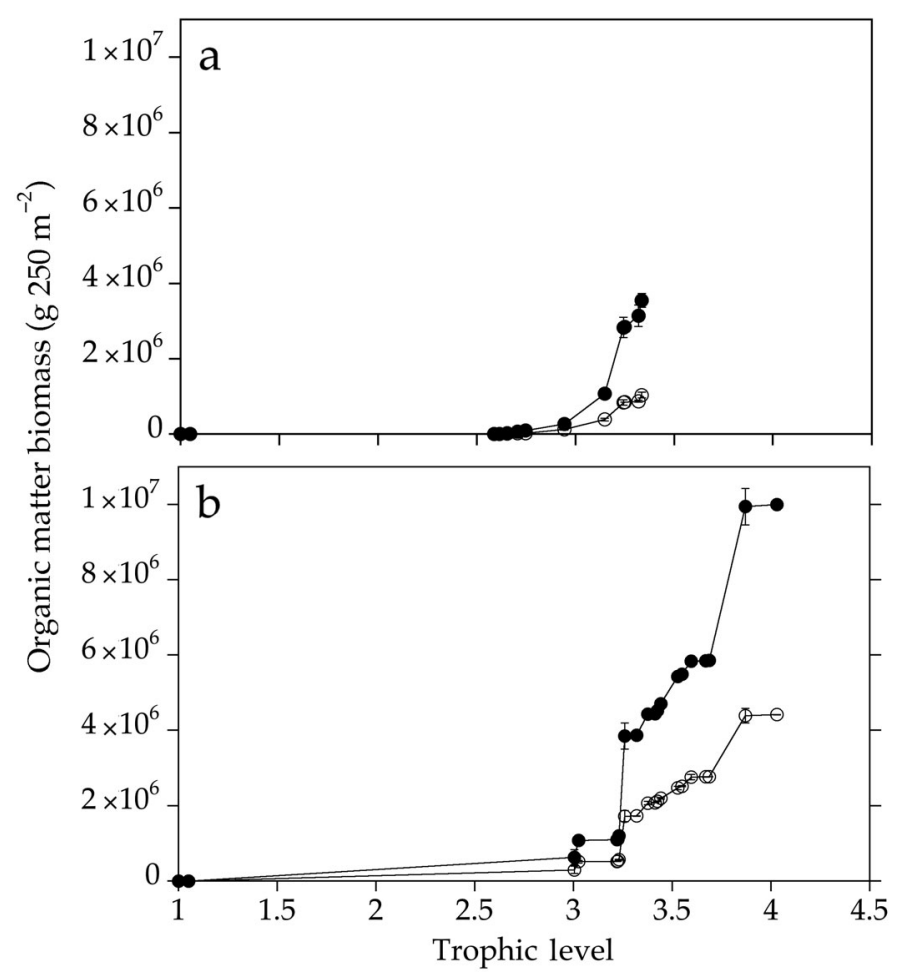

Fig. 5. Cumulative organic matter (๑) and organic matter derived from macroalgae $(O)$ that supported the reef fish assemblage $\left(\mathrm{g} 250 \mathrm{~m}^{-2}\right.$ ) versus trophic level for (a) the Marlborough Sounds and (b) Fiordland reef fish communities. Values for the total organic matter required to support each species are given as mean $\pm \mathrm{SE}$

derived from macroalgae and 2.29 times more organic matter derived from phytoplankton than the Marlborough Sounds reef fish community.

The use of different transfer efficiencies altered the estimates of the magnitude of regional differences in organic matter required to support each community. This difference was primarily due to regional differences in the magnitude of fish biomass and the distribution of biomass among trophic levels (Table 2, Fig. 7). However, the regional difference in organic matter required to support the fish community remained significantly different for transfer efficiencies ranging from 0.05 to 0.2 (Table 2 ).

\section{DISCUSSION}

The data and results presented here demonstrate that the observed differences in organic matter supply to, and trophic structure of, reef fish communities between the Marlborough Sounds and Fiordland resulted in important regional differences in the trophodynamics of the reef fish communities. The relationships between incorporation of organic mat-
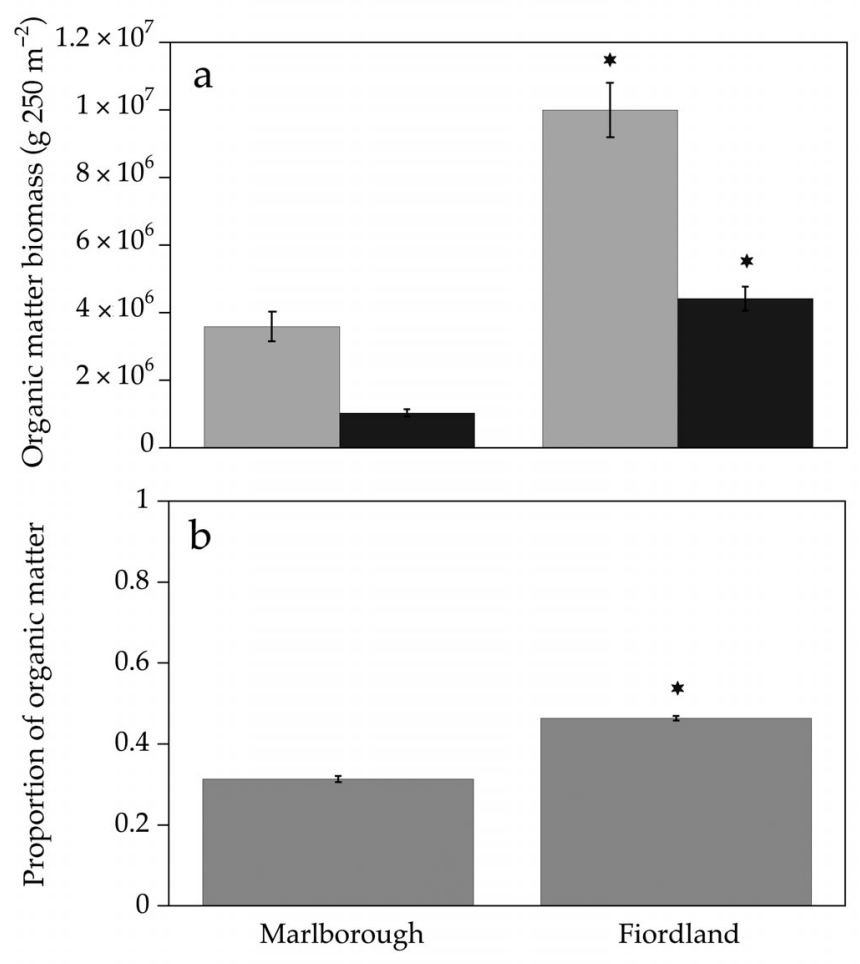

Fig. 6. (a) Average total organic matter (g $\left.250 \mathrm{~m}^{-2}\right)(\square)$ and organic matter derived from macroalgae (ם) required to support the fish community and (b) the proportion of organic matter derived from macroalgae. Mean $\pm \mathrm{SE}^{*}{ }^{*}$ significant regional differences at $\mathrm{p}<0.05$

Table 2. Results from GLMs on the regional difference in organic matter required to support the fish communities, as calculated using a range of values for trophic efficiency. All values are significant at $\mathrm{p}<0.05$ )

\begin{tabular}{|lcrc|}
\hline $\begin{array}{l}\text { Transfer } \\
\text { efficiency }\end{array}$ & $\begin{array}{c}\text { Effect } \\
\text { size }\end{array}$ & $F_{1,189}$ & $\mathrm{p}$ \\
\hline 0.05 & 3.73 & 12.96 & 0.001 \\
0.075 & 3.21 & 12.02 & 0.002 \\
0.1 & 2.91 & 11.26 & 0.002 \\
0.125 & 2.71 & 10.61 & 0.003 \\
0.15 & 2.57 & 10.06 & 0.004 \\
0.175 & 2.46 & 9.59 & 0.004 \\
0.2 & 2.37 & 9.18 & 0.005 \\
\hline
\end{tabular}

ter derived from macroalgae into food webs, distribution of biomass across trophic levels, and the amount of organic matter required to support the fish community differed significantly between the 2 regions. These data highlight the importance of kelp forest habitats as sources of basal organic matter for supporting coastal food webs, in addition to their role as providers of critical biogenic habitat, and provide a framework for considering trophodynamics of fish in the context of ecosystem-based management. 


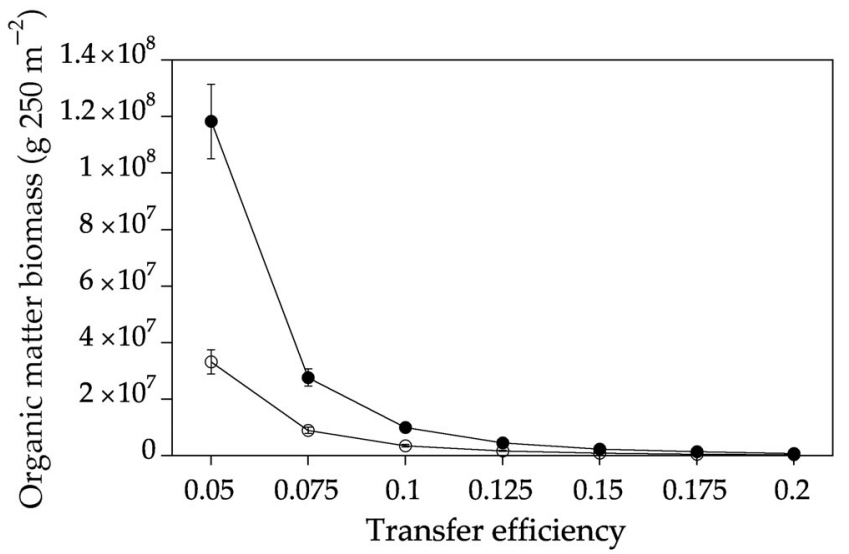

Fig. 7. Estimates of organic matter required to support the fish community in Fiordland (-) and the Marlborough Sounds $(\mathrm{O})$, obtained using varying values for trophic trans fer efficiency. Mean $\pm \mathrm{SE}$

A lower proportion of total fish biomass was supported by organic matter derived from macroalgae in the Marlborough Sounds, relative to that observed for the fish community from Fiordland (Figs. $2 \& 3$ ). In addition, the observed declining contribution of organic matter derived from macroalgae with trophic level in the Marlborough Sounds is consistent with theoretical predictions on limitation of organic matter available to support food webs (Fig. 4). In the Marlborough Sounds, the higher trophic level species increasingly relied on food webs linked to pelagic subsidies rather than autochthonous macroalgae. Many high trophic level temperate reef fish exhibit dietary shifts based on resource availability (Cowen 1986, Hamilton et al. 2011, Jack \& Wing 2011, Beer \& Wing 2013). Here an increased reliance of higher trophic level fishes on phytoplankton-derived food webs indicated that this was likely the most available resource in the Marlborough Sounds, based on the mobile consumer adaptive response hypothesis (McCann \& Rooney 2009). In contrast, the proportion of fish biomass supported by organic matter derived from macroalgae in Fiordland did not change with trophic level, indicating that there was sufficient macroalgae production available to the fish community to support the energy requirements of higher trophic level species. Patterns of organic matter use observed in the Fiordland fish community matched theoretical predictions of coupling of different energy channels in food webs when availability of both sources was non-limiting (Rooney et al. 2006).

While the patterns we observed match theoretical predictions, several important caveats must accompany our conclusions. For example, the decreasing contribution of organic matter derived from macroalgae to fish biomass as trophic level increases in the
Marlborough Sounds may have been due to a lack of transfer of macroalgae-derived organic matter to high trophic level species, rather than a lack of macroalgae production. Due to larger body sizes, herbivorous and omnivorous fish have lower predation rates than many zooplanktivorous fishes (Stevenson et al. 2007, Young et al. 2010, Truong et al. 2017), which could reduce the transfer of macroalgae-derived organic matter to higher trophic levels. However, fish on temperate reefs have been observed to feed primarily on invertebrates rather than fish (Page et al. 2013), with the high trophic level fish species being generalist omnivores rather than exclusively piscivorous (Russell 1983, Jones 1988). As many reef invertebrates graze on macroalgae (Hobson \& Chess 2001, Koenigs et al. 2015), the prey base linked to macroalgae-derived organic matter would be available to reef fish even in the absence of predation on herbivorous fishes.

Allochthonous primary production from phytoplankton is a large organic matter source that may be adequate to support the fish community in the absence of macroalgae inputs (Cresson et al. 2014, Champion et al. 2015). Despite the high observed inputs of organic matter derived from macroalgae to food webs supporting the Fiordland reef fish community, phytoplankton supports approximately half $(50.68 \%)$ of the fish biomass. These data are consistent with observations that both phytoplankton and macroalgae production are important sources of organic matter for temperate reef fish communities (McMeans et al. 2013, Koenigs et al. 2015, Truong et al. 2017). If there was sufficient supply of phytoplankton, the increased reliance on pelagic subsidies in the Marlborough Sounds fish community may not have affected the magnitude of fish production (Downing et al. 1990, Ware \& Thomson 2005). Nevertheless, increased reliance on a single organic matter source is likely to reduce the stability of supply of organic matter to the food web (Rooney et al. 2006). Here fish community production, particularly production of high trophic level species, is likely to be more variable as it is more vulnerable to perturbations in pelagic productivity than if the community was supported by a more equal, and diverse, mix of organic matter sources (Doak et al. 1998). The species occupying the highest trophic levels in the Marlborough Sounds are all exploited species: tarakihi Nemadactylus macropterus, kahawai Arripis trutta, red moki Cheilodactylus spectabilis and blue cod Parapercis colias. Therefore, the observed patterns have important implications for understanding mechanisms for variability in fisheries production. 
The Fiordland fish community had higher fish biomass density and more fish biomass at higher trophic levels, relative to the fish community in the Marlborough Sounds. As a consequence, the Fiordland fish community required more organic matter to support the underlying food webs that made up its prey base (Figs. 5 \& 6). Total fish biomass density was 1.72 times higher in Fiordland than in the Marlborough Sounds, yet in Fiordland the fish community converted 2.91 times more organic matter into fish biomass. As $90 \%$ of biomass is lost with each trophic transfer (Pauly \& Christensen 1995), the small regional differences in distribution of biomass across trophic levels translated into large differences in the amount of organic matter converted into reef fish biomass. Observations of greater fish biomass at higher trophic levels in Fiordland, relative to those observed in the Marlborough Sounds, is consistent with a larger and more diverse base of productivity in Fiordland. This observation is consistent with the idea that food web complexity has been observed to be positively influenced by productivity at the base (Oksanen et al. 1981, Persson et al. 1992, Vander Zanden et al. 1999). Further, there was a large regional difference in the total volume of basal organic matter derived from macroalgae (4.44 times more in Fiordland) versus that derived from phytoplankton (2.29 times more in Fiordland). Nevertheless, the biomass of reef fish per unit area supported by organic matter derived from phytoplankton was not statistically different between regions. Consequently, the difference in observed magnitude of reef fish biomass per unit area between the regions was primarily comprised of fish biomass supported by organic matter derived from macroalgae. This result highlights the effects of greater inputs of macroalgae-derived organic matter on the reef fish community in Fiordland, relative to those in the Marlborough Sounds, in terms of biomass density of coastal fish.

Community biomass is often thought to be a function of habitat productivity (Randall \& Minns 2000), indicating that Fiordland is likely a more productive marine environment than the Marlborough Sounds. However, fish biomass may not be an appropriate measure of habitat productivity if one community is subject to higher levels of exploitation (Minns et al. 2011) or natural mortality. Hence, the lower fish biomass in the Marlborough Sounds, relative to that observed in Fiordland, may alternatively be attributable to heavier fishing pressure as opposed to a reflection of the organic matter available to support food webs. If this was the case, differences in modifications of the fish community wrought by fishing between regions may have resulted in differences in how organic matter was converted into fish biomass.

Regardless of the trophic efficiency used to calculate the organic matter required to sustain the reef fish community, the energetic requirements of the Fiordland fish community were consistently higher than those of the Marlborough fish community (Fig. 7). The magnitude of the regional difference, however, was affected by trophic efficiency, indicating we may have over- or under-estimated the amount of organic matter required by using the average $10 \%$ value for the majority of calculations (Pauly \& Christensen 1995). Further, as transfer efficiency may decrease with increasing trophic level (Ware 2000, Barnes et al. 2010), we may have underestimated the regional difference in organic matter use, as there was more biomass at higher trophic levels in Fiordland.

The present study only quantified fish biomass rather than fish production (i.e. the rate of change in biomass). As fish biomass and fish production are generally correlated (Downing \& Plante 1993, Randall et al. 1995), fish production was likely higher in Fiordland than in the Marlborough Sounds. However, there are other variables that may affect the production-biomass ratio (Randall et al. 1995, Minns et al. 2011), and hence our estimates of total fish biomass may not directly reflect regional differences in fish production. For example, there is evidence that the growth rate of some temperate reef species increases with increased contribution of organic matter derived from macroalgae at the base of the food web (Beer \& Wing 2013, Markel \& Shurin 2015). Consequentially, the magnitude of the regional difference in fish production may be larger than the regional difference in total fish biomass, as the Fiordland community utilizes more macroalgae-derived organic matter. The assumption that higher fish biomass resulted in greater fish production was also dependent on the 2 communities having comparable average fish size and growth rates (Randall et al. 1995). Inclusion of growth rates in further research would aid in better resolution of differences in the productive capacity of fish communities between the Marlborough Sounds and Fiordland (Minns et al. 2011).

The estimates of biomass distribution amongst trophic positions in the present study used regional averages for the trophic position of each species. Though the estimates included variation at the transect and site level, based on different relative abundances of reef fishes, the estimates did not include transect or site level variation in trophic position. Notably, there can be considerable small-scale intraspecific variation in trophic position within a region 
in some systems (Hamilton et al. 2011, Wing et al. 2012). Due to the large spatial extent of inputs of organic matter derived from macroalgae to coastal food webs (Duggins et al. 1989, Krumhansl \& Scheibling 2012), a regional scale approach to estimating organic matter fluxes was deemed most suitable.

The results presented here demonstrate that there were dramatic differences in the trophodynamics of reef fish communities between 2 contrasting regions: the Marlborough Sounds and Fiordland. The results provide further support for the hypothesis that the supply of macroalgae-derived organic matter to the reef fish community was limited in the Marlborough Sounds. Marine heat waves and extensive conversion of native forest to agriculture and development, resulting in increased sediment loading, as well as losses of important sea urchin predators have been linked to a loss of kelp bed habitats in the Marlborough Sounds (Hay 1990, Davidson et al. 2014, Handley 2016). Both Hay (1990) and Handley (2016) report decadal scale decreases in the primary canopy forming species Macrocystis pyrifera in the region with links to ocean warming, sedimentation and formation of sea urchin barren grounds. Here there was likely an important interaction between differences in production in organic matter source pools, in this case low inputs of organic matter derived from kelp forest habitats, and reduced abundance of higher trophic level omnivorous species wrought from increases in fishing-induced mortality in the region. The observed contrast in coastal food web structure between regions provides an important case study for how changes in kelp forest habitat influence food web connectivity within coastal marine ecosystems.

Kelp forest habitats are under threat globally (Krumhansl et al. 2016) with observations of reductions and shifts in range linked to climate change (Dayton et al. 1999, Byrnes et al. 2011, Wernberg et al. 2016) alongside wide scale degradation of coastal environmental conditions (Dayton et al. 1998, Connell et al. 2008) and reductions in predation on sea urchins which coalesce resulting in regime shifts to barren habitat (Steneck et al. 2004, Filbee-Dexter \& Scheibling 2014). One of the clear consequences of losses in kelp forests is a reduction in availability of biogenic habitat (e.g. Wing et al. 2015). A more cryptic consequence is how losses in production of organic matter from kelp forests influence food web connectivity and trophodynamics at the regional scale (e.g. Salomon et al. 2008). These issues are directly relevant to successful implementation of ecosystem-based management in coastal marine systems as one of the central goals of the approach is to preserve ecosystem con- nectivity and processes that result in provision of ecosystem services in the context of multiple uses (Pikitch et al. 2004, Arkema et al. 2006, Levin \& Lubchenco 2008). Organic matter and nutrients are the currency of food webs, and thus a vital component of ecosystem connectivity and function. The results of the present study highlight the consequences of contraction in kelp forest habitat for food web connectivity and coastal fish productivity. Regardless of the drivers of the observed differences in incorporation of kelpbased organic matter within food webs, the results emphasize the importance of considering regional stressors on production in basal organic matter source pools, particularly those from sensitive kelp forest habitats, when applying ecosystem-based approaches to managing coastal resources and biodiversity.

Acknowledgements. We thank Robert van Hale, Alex Connolly, Jack Hall, Lucy Wing, Bill Dickson, Evan Kenton and 2 anonymous reviewers for assistance with this work. Technical support was provided from the Departments of Marine Science and Chemistry at the University of Otago. Monetary support was provided from the National Science Challenge: Sustainable Seas (4.1.1 Ecosystem Connectivity) the Royal Society of New Zealand Marsden Fund (UOO1008) and from the University of Otago's Research Committee.

\section{LITERATURE CITED}

Arkema KK, Abramson SC, Dewsbury BM (2006) Marine ecosystem-based management: from characterization to implementation. Front Ecol Environ 4:525-532

*Barnes C, Maxwell D, Reuman DC, Jennings S (2010) Global patterns in predator-prey size relationships reveal size dependency of trophic transfer efficiency. Ecology 91:222-232

* Beer NA, Wing SR (2013) Trophic ecology drives spatial variability in growth among subpopulations of an exploited temperate reef fish. NZ J Mar Freshw Res 47:73-89

*Bornes JE, Reed DC, Cardinale BJ, Cavanaugh KC, Holbrook SJ, Schmitt RJ (2011) Climate-driven increases in storm frequency simplify kelp forest food webs. Glob Change Biol 17:2513-2524

* Champion C, Suthers IM, Smith JA (2015) Zooplanktivory is a key process for fish production on a coastal artificial reef. Mar Ecol Prog Ser 541:1-14

Connell SD, Russell BD, Turner DJ, Shepherd SA and others (2008) Recovering a lost baseline: missing kelp forests from a metropolitan coast. Mar Ecol Prog Ser 360:63-72

* Cowen RK (1986) Site-specific differences in the feeding ecology of the California sheephead, Semicossyphus pulcher (Labridae). Environ Biol Fishes 16:193-203

* Cresson P, Ruitton S, Harmelin-Vivien M (2014) Artificial reefs do increase secondary biomass production: mechanisms evidenced by stable isotopes. Mar Ecol Prog Ser 509:15-26

* Davenport AC, Anderson TW (2007) Positive indirect effects of reef fishes on kelp performance: the importance of mesograzers. Ecology 88:1548-1561 
Davidson R, Richards L, Abel W, Avis M (2014) Long IslandKokomohua Marine Reserve, Queen Charlotte Sound: update of biological monitoring, 1992-2014. Survey and Monitoring Report No 796. Davidson Environmental, Nelson

Dayton PK, Tegner MJ, Edwards PB, Riser KL (1998) Sliding baselines, ghosts, and reduced expectations in kelp forest communities. Ecol Appl 8:309-322

* Dayton PK, Tegner MJ, Edwards PB, Riser KL (1999) Temporal and spatial scales of kelp demography: the role of oceanographic climate. Ecol Monogr 69:219-250

* Deniro MJ, Epstein S (1978) Influence of diet on distribution of carbon isotopes in animals. Geochim Cosmochim Acta 42:495-506

×eniro MJ, Epstein S (1981) Influence of diet on the distribution of nitrogen isotopes in animals. Geochim Cosmochim Acta 45:341-351

Doak DF, Bigger D, Harding EK, Marvier MA, O'Malley RE, Thomson D (1998) The statistical inevitability of stabilitydiversity relationships in community ecology. Am Nat 151:264-276

* Docmac F, Araya M, Hinojosa IA, Dorador C, Harrod C (2017) Habitat coupling writ large: pelagic-derived materials fuel benthivorous macroalgal reef fishes in an upwelling zone. Ecology 98:2267-2272

Downing JA, Plante C (1993) Production of fish populations in lakes. Can J Fish Aquat Sci 50:110-120

* Downing JA, Plante C, Lalonde S (1990) Fish production correlated with primary productivity, not the morphoedaphic index. Can J Fish Aquat Sci 47:1929-1936

* Duggins DO, Simenstad CA, Estes JA (1989) Magnification of secondary production by kelp detritus in coastal marine ecosystems. Science 245:170-173

Filbee-Dexter K, Scheibling RE (2014) Sea urchin barrens as alternative stable states of collapsed kelp ecosystems. Mar Ecol Prog Ser 495:1-25

Fredriksen S (2003) Food web studies in a Norwegian kelp forest based on stable isotope $\left(\delta^{13} \mathrm{C}\right.$ and $\left.\delta^{15} \mathrm{~N}\right)$ analysis. Mar Ecol Prog Ser 260:71-81

Friedland KD, Stock C, Drinkwater KF, Link JS and others (2012) Pathways between primary production and fisheries yields of large marine ecosystems. PLOS ONE 7: e28945

Fry B (2006) Stable isotope ecology. Springer, New York, NY

*Graham MH (2004) Effects of local deforestation on the diversity and structure of Southern California giant kelp forest food webs. Ecosystems 7:341-357

Hamilton SL, Caselle JE, Lantz CA, Egloff TL and others (2011) Extensive geographic and ontogenetic variation characterizes the trophic ecology of a temperate reef fish on southern California (USA) rocky reefs. Mar Ecol Prog Ser 429:227-244

Hamilton SL, Newsome SD, Caselle JE (2014) Dietary niche expansion of a kelp forest predator recovering from intense commercial exploitation. Ecology 95:164-172

Handley S (2016) History of benthic change in Queen Charlottes Sound/Totaranui, Marlborough. Prepared for Marlborough District Council. National Institute of Water and Atmospheric Research, Nelson

* Hay CH (1990) The distribution of Macrocystis pyrifera (Phaeophyta: Laminariales) as a biological indicator of cool sea surface temperature, with special reference to New Zealand waters. J R Soc NZ 20:313-336

Hobson ES, Chess JR (2001) Influence of trophic relations on form and behavior among fishes and benthic inverte- brates in some California marine communities. Environ Biol Fishes 60:411-457

Jack L, Wing SR (2011) Individual variability in trophic position and diet of a marine omnivore is linked to kelp bed habitat. Mar Ecol Prog Ser 443:129-139

Jack L, Wing SR, McLeod RJ (2009) Prey base shifts in red rock lobster Jasus edwardsii in response to habitat conversion in Fiordland marine reserves: implications for effective spatial management. Mar Ecol Prog Ser 381: 213-222

Johnson CR, Banks SC, Barrett NS, Cazassus F and others (2011) Climate change cascades: Shifts in oceanography, species' ranges and subtidal marine community dynamics in eastern Tasmania. J Exp Mar Biol Ecol 400:17-32

Jones GP (1988) Ecology of rocky reef fish of north eastern New Zealand: a review. NZ J Mar Freshw Res 22:445-462

Koenigs C, Miller RJ, Page HM (2015) Top predators rely on carbon derived from giant kelp Macrocystis pyrifera. Mar Ecol Prog Ser 537:1-8

Koenigstein S, Mark FC, Gossling-Reisemann S, Reuter H, Poertner HO (2016) Modelling climate change impacts on marine fish populations: process-based integration of ocean warming, acidification and other environmental drivers. Fish Fish 17:972-1004

Krumhansl KA, Scheibling RE (2012) Production and fate of kelp detritus. Mar Ecol Prog Ser 467:281-302

KKrumhansl KA, Okamoto DK, Rassweiler A, Novak M and others (2016) Global patterns of kelp forest change over the past half-century. Proc Natl Acad Sci USA 113: 13785-13790

KLevin SA, Lubchenco J (2008) Resilience, robustness, and marine ecosystem-based management. Bioscience 58: 27-32

Mann KH (1973) Seaweeds: their productivity and strategy for growth. Science 182:975-981

* Markel RW, Shurin JB (2015) Indirect effects of sea otters on rockfish (Sebastes spp.) in giant kelp forests. Ecology 96: 2877-2890

* McCann KS, Rooney N (2009) The more food webs change, the more they stay the same. Philos Trans R Soc B 364: 1789-1801

*McCutchan JH Jr, Lewis WM Jr, Kendall C, McGrath CC (2003) Variation in trophic shift for stable isotope ratios of carbon, nitrogen, and sulfur. Oikos 102:378-390

*McLeod RJ, Wing SR, Skilton JE (2010a) High incidence of invertebrate-chemoautotrophic symbioses supports the macro-infaunal community in the New Zealand fjords. Limnol Oceanogr 55:2097-2106

McLeod RJ, Wing SR, Davis JP (2010b) Habitat conversion and species loss alters the composition of carbon sources to benthic communities. Mar Ecol Prog Ser 411:127-136

McMeans BC, Rooney N, Arts MT, Fisk AT (2013) Food web structure of a coastal Arctic marine ecosystem and implications for stability. Mar Ecol Prog Ser 482:17-28

*Mill AC, Pinnegar JK, Polunin NVC (2007) Explaining isotope trophic-step fractionation: why herbivorous fish are different. Funct Ecol 21:1137-1145

*Miller RJ, Page HM (2012) Kelp as a trophic resource for marine suspension feeders: a review of isotope-based evidence. Mar Biol 159:1391-1402

Miller SM, Wing SR, Hurd CL (2006) Photoacclimation of Ecklonia radiata (Laminariales, Heterokontophyta) in Doubtful Sound, Fiordland. Phycologia 45:44-52

* Minns CK, Randall RG, Smokorowski KE, Clarke KD and others (2011) Direct and indirect estimates of the produc- 
tive capacity of fish habitat under Canada's Policy for the Management of Fish Habitat: where have we been, where are we now, and where are we going? Can J Fish Aquat Sci 68:2204-2227

Newsome SD, Bentall GB, Tinker MT, Oftedal OT, Ralls K, Estes JA, Fogel ML (2010) Variation in $\delta^{13} \mathrm{C}$ and $\delta^{15} \mathrm{~N}$ dietvibrissae trophic discrimination factors in a wild population of California sea otters. Ecol Appl 20:1744-1752

* Norderhaug KM, Nygaard K, Fredriksen S (2006) Importance of phlorotannin content and $\mathrm{C}: \mathrm{N}$ ratio of Laminaria hyperborea in determining its palatability as food for consumers. Mar Biol Res 2:367-371

* Oksanen L, Fretwell SD, Arruda J, Niemela P (1981) Exploitation ecosystems in gradients of primary productivity. Am Nat 118:240-261

Page HM, Brooks AJ, Kulbicki M, Galzin R and others (2013) Stable isotopes reveal trophic relationships and diet of consumers in temperate kelp forest and coral reef ecosystems. Oceanography (Wash DC) 26:180-189

*Pauly D, Christensen V (1995) Primary production required to sustain global fisheries. Nature 374:255-257

* Persson L, Diehl S, Johansson L, Andersson G, Hamrin SF (1992) Trophic interactions in temperate lake ecosystems: a test of food-chain theory. Am Nat 140:59-84

Persson L, Van Leeuwen A, De Roos AM (2014) The ecological foundation for ecosystem-based management of fisheries: mechanistic linkages between the individual-, population-, and community-level dynamics. ICES J Mar Sci 71:2268-2280

* Phillips DL, Gregg JW (2001) Uncertainty in source partitioning using stable isotopes. Oecologia 127:171-179

* Pikitch EK, Santora C, Babcock EA, Bakun A and others (2004) Ecosystem-based fishery management. Science 305:346-347

* Post DM (2002) Using stable isotopes to estimate trophic position: models, methods, and assumptions. Ecology 83: 703-718

* Post DM, Layman CA, Arrington DA, Takimoto G, Quattrochi J, Montana CG (2007) Getting to the fat of the matter: models, methods and assumptions for dealing with lipids in stable isotope analyses. Oecologia 152:179-189

Randall RG, Minns CK (2000) Use of fish production per unit biomass ratios for measuring the productive capacity of fish habitats. Can J Fish Aquat Sci 57:1657-1667

Kandall RG, Kelso JRM, Minns CK (1995) Fish production in fresh-waters: are rivers more productive than lakes. Can J Fish Aquat Sci 52:631-643

Rooney N, McCann K, Gellner G, Moore JC (2006) Structural asymmetry and the stability of diverse food webs. Nature 442:265-269

Russell BC (1983) The food and feeding-habits of rocky reef fish of north-eastern New Zealand. NZ J Mar Freshw Res 17:121-145

Salomon AK, Shears NT, Langlois TJ, Babcock RC (2008) Cascading effects of fishing can alter carbon flow through a temperate coastal ecosystem. Ecol Appl 18: 1874-1887

Shears NT, Babcock RC (2007) Quantitative description of mainland New Zealand's shallow subtidal reef communities. Science for Conservation 280. Department of Conservation, Wellington

Skinner MM, Martin AA, Moore BC (2016) Is lipid correction necessary in the stable isotope analysis of fish tissues? Rapid Commun Mass Spectrom 30:881-889
Steneck RS, Graham MH, Bourque BJ, Corbett D, Erlandson JM, Estes JA, Tegner MJ (2002) Kelp forest ecosystems: biodiversity, stability, resilience, and future. Environ Conserv 29:436-459

* Steneck RS, Vavrinec J, Leland AV (2004) Accelerating trophic-level dysfunction in kelp forest ecosystems of the western North Atlantic. Ecosystems 7:323-332

Stevenson C, Katz LS, Micheli F, Block B and others (2007) High apex predator biomass on remote Pacific islands. Coral Reefs 26:47-51

Tallis HM, Wing SR, Frew RD (2004) Historical evidence for habitat conversion and local population decline in a New Zealand fjord. Ecol Appl 14:546-554

* Thomas CJ, Cahoon LB (1993) Stable isotope analyses differentiate between different trophic pathways supporting rocky-reef fishes. Mar Ecol Prog Ser 95:19-24

* Trebilco R, Dulvy NK, Anderson SC, Salomon AK (2016) The paradox of inverted biomass pyramids in kelp forest fish communities. Proc Biol Sci 283:20160816

* Truong L, Suthers IM, Cruz DO, Smith JA (2017) Plankton supports the majority of fish biomass on temperate rocky reefs. Mar Biol 164:73

V Vander Zanden MJ, Vadeboncoeur Y (2002) Fishes as integrators of benthic and pelagic food webs in lakes. Ecology 83:2152-2161

*Vander Zanden MJ, Shuter BJ, Lester N, Rasmussen JB (1999) Patterns of food chain length in lakes: a stable isotope study. Am Nat 154:406-416

* von Biela VR, Newsome SD, Bodkin JL, Kruse GH, Zimmerman CE (2016) Widespread kelp-derived carbon in pelagic and benthic nearshore fishes suggested by stable isotope analysis. Estuar Coast Shelf Sci 181:364-374

Ware DM (2000) Aquatic ecosystems: properties and models. In: Harrison PJ, Parsons, T. R. (ed) Fisheries oceanography: an integrative approach to fisheries ecology and management. University Press, Cambridge

*Ware DM, Thomson RE (2005) Bottom-up ecosystem trophic dynamics determine fish production in the Northeast Pacific. Science 308:1280-1284

*Watson RA, Nowara GB, Tracey SR, Fulton EA and others (2013) Ecosystem model of Tasmanian waters explores impacts of climate-change induced changes in primary productivity. Ecol Modell 264:115-129

*Wernberg T, Bennett S, Babcock RC, de Bettignies T and others (2016) Climate-driven regime shift of a temperate marine ecosystem. Science 353:169-172

* Wing SR, Jack L (2014) Fiordland: the ecological basis for ecosystem management. NZ J Mar Freshw Res 48:577-593

*Wing SR, Leichter JJ, Perrin C, Rutger SM, Bowman MH, Cornelisen CD (2007) Topographic shading and wave exposure influence morphology and ecophysiology of Ecklonia radiata (C. Agardh 1817) in Fiordland, New Zealand. Limnol Oceanogr 52:1853-1864

Wing SR, Beer NA, Jack L (2012) Resource base of blue cod Parapercis colias subpopulations in marginal fjordic habitats is linked to chemoautotrophic production. Mar Ecol Prog Ser 466:205-214

Wing SR, Jack LC, Fujita Y (2015) Overthrowing a regime shift: displacement of sea urchins by abalone in a kelp forest ecosystem. Ecosphere 6:268

* Young JW, Lansdell MJ, Campbell RA, Cooper SP, Juanes F, Guest MA (2010) Feeding ecology and niche segregation in oceanic top predators off eastern Australia. Mar Biol 157:2347-2368

Submitted: September 25, 2018; Accepted: April 21, 2019

Proofs received from author(s): June 17, 2019 